\title{
KONVERGENSI PEMIKIRAN ETIKA SOSIAL GUS DUR DAN ETIKA UTILITARIANISME
}

\author{
M. Nur Fauzi \\ Institut Agama Islam (IAI) Darussalam Blokagung Banyuwangi \\ Email: fauzinur78@gmail.com
}

\begin{abstract}
This paper tries to explore the consep of mașlaha of Abdurrahman Wahid as known better call his name by Gus Dur and it's convergence with the utilitarianism ethics. This research starting from the deep curiousity intellectual the writer after saw he's thinking in few media as such as the magazine, newspaper today, and his books that has codificated in the famous publisher in Indonesia. Even he's - as we known - never wrote his thinking in a full books as such as academic type, however if we seen of his thinks could be understood if in every his ideas has a metodology and a current basic approach. From this describe we have a few problem research, first, how the truth the concept of mașlaḥa Abdurrahman Wahid; second, how the convergence of his mașlaḥa base ethics thinking with the utilitarianism ethics; third, how the relevance his mașlaha based ethics thinking in Indonesia today. This research was library studies that use the deductive and inductive methode. Meanwhile, the research use a few approaches as such as historical-philosopys and descriptive-analysis. This discourse seen important because almost never found the thinking that describe of the concept of mașlaha based ethics of Abdurrahman Wahid especially from islamic law perspective.
\end{abstract}

Keywords: social ethics, utilitarianism etbics, the convergence, mașlah a

\section{Pendahuluan}

Sebagaimana sudah menjadi kesepakatan umum bahwa Indonesia adalah negara yang bercorak plural dan bahkan multikultural. Selain itu Indonesia adalah negara dengan mayoritas penduduk yang beragama Islam. Tapi meskipun demikian, pola keberagamaan di Indonesia disinyalir dapat tumbuh dan berkembang secara alamiah dan bisa berjalan berdampingan antar pemeluk agama. Harmonisasi hubungan antar umat beragama yang terjalin di Indonesia tidak bisa dilepaskan dari peran para pemuka agama dan cendekiawan muslim yang memiliki kepedulian dalam menanamkan nilai-nilai dasar ajaran agama yang bersifat universal. Setiap agama dipastikan menyeru kepada kebenaran dan kebaikan bagi sesama umat manusia tanpa terkecuali. Demikian memang adanya, agama diperuntukkan bagi kemaslahatan umat manusia (li mașlahah al- 
'ämmab) dan memberikan kemanfaatan yang sebesar-besarnya bagi kemanusiaan.

Dalam konteks pembumian pemikiran hukum Islam di Indonesia, sebagaimana disinggung di atas, Gus Dur merupakan salah seorang cendekiawan muslim yang memiliki concern mendalam tentang hal ini. Di era 1980-an Gus Dur sempat melandingkan gagasan tentang pribumisasi Islam. Gagasan ini sempat menuai pro dan kontra pada waktu itu. Inti dari gagasan tersebut adalah bagaimana Islam mampu berdialektika dan berdialog secara dinamis dan kreatif dengan pengetahuan dan nilai-nilai budaya masyarakat setempat. Jika ini yang terjadi, dalam arti Islam telah menjadi denyut nadi dan bersatu dalam alunan napas keindonesiaan kita, maka mengusung Islam secara formalistik menjadi tidak relevan, kurang menarik dan jauh dari semangat zamannya.

Saat ini, mendekati empat puluh tahun dari dilontarkannya ide dan gagasan tersebut di era 80-an, gagasan Gus Dur tersebut kini mendapat tantangan serius dari kalangan yang berupaya mempopulerkan kembali ide tentang perlunya menegakkan negara Islam (kbilafah Islamiyyah). Gagasan yang diusung oleh aliran ini tentu saja mengarah pada pemaknaan Islam secara literal, kaku (rigid), dan syarat dengan klaim-kliam kebenaran (truth claim) karena mengandaikan tafsirannya adalah yang paling benar.

Penggambaran realitas sosial keindonesiaan kita di atas semakin menegaskan tentang keniscayaan untuk mengaktualkan kembali gagasan pribumisasi Islam tersebut yang pada intinya mengarah pada pemaknaan Islam sebagai etika sosial. Sebuah tafsir Islam yang tidak hanya memihak kepada mainstream umat Islam sebagai kalangan mayoritas, tetapi juga mengayomi golongan minoritas di Indonesia.

\section{Paradigma dan Tipologi Pembaruan Hukum Islam}

Islam merupakan agama yang diturunkan bagi umat manusia dan relevan dengan konteks zamannya (șälih li kulli zamān wa makän). Oleh karena itu, para cendekiawan muslim terus berupaya untuk mengadakan pembaruan-pembaruan tersebut sesuai dengan kapasitas dan kapabilitas masing-masing keilmuannya. Dari pembaruan yang bercorak individual hingga mewujud dalam sebuah gerakan pembaruan.

Dalam lanskap implementasi Islam di ranah keindonesiaan yang plural dan multikultural ini paling tidak bisa dipetakan ke dalam dua aliran besar, yakni mazhab Islam legal-eksklusif dan mazhab Islam substantif-inklusif. ${ }^{1}$ Mazhab

${ }^{1}$ Lihat Kata Pengantar M. Syafi'i Anwar, Islamku, Islam Anda, Islam Kita Membingkai Potret Pemikiran Politik KH Abdurrahman Wahid dalam Abdurrahman Wahid, Islamku Islam Anda Islam Kita Agama Masyarakat Negara Demokrasi (Jakarta: The Wahid Institute, 2006), xvii. 
Islam legal-eksklusif memimpikan dan bercita-cita terlaksananya ajaran Islam secara formal dalam ranah institusi kenegaraan dan masyarakat. Islam menurut aliran ini haruslah menjadi warna tunggal bagi hitam putihnya realitas keindonesiaan yang plural dan majemuk. Sementara itu mazhab Islam substantif-inklusif lebih melihat kepada realitas sosio-kultural masyarakat di mana Islam dilabuhkan. Dengan demikian dalam konteks keindonesiaan, Islam tidak harus dimaknai secara formalistik, Islam tidak harus menjadi mazhab negara. Sebaliknya, Islam harus mampu berdialektika dan berdialog dengan nilai-nilai budaya dan kearifan lokal masyarakat setempat. Singkatnya bagaimana memarketkan Islam sebagai etika sosial. ${ }^{2}$

Apabila diskemakan maka paradigma pemikiran hukum Islam dapat dicermati seperti di bawah ini:
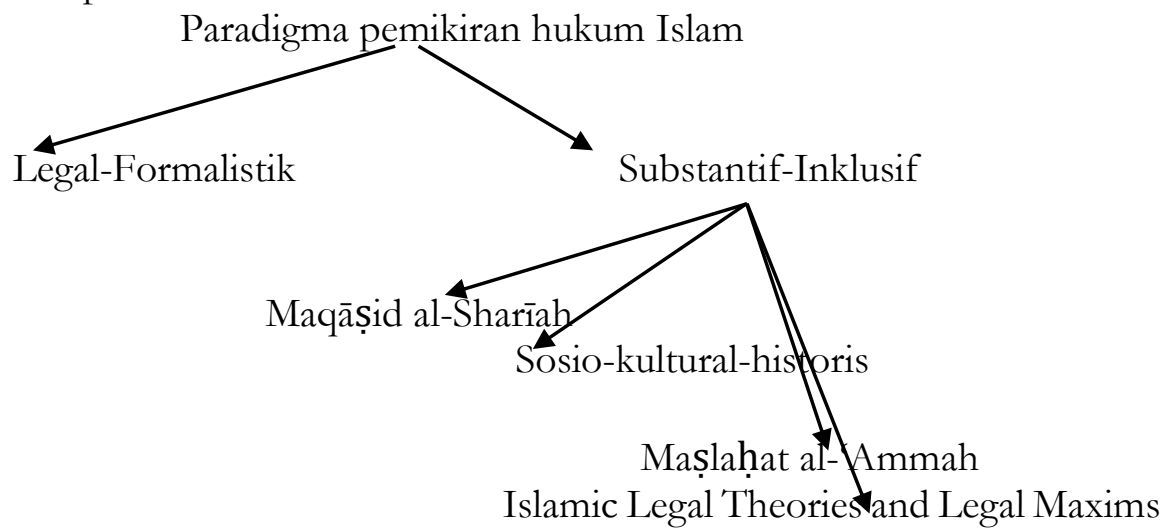

Dalam konteks gerakan pembaruan hukum Islam pada dasarnya dapat dibagi menjadi dua kelompok: pertama, sekelompok orang (legal theorists) yang berpendapat bahwa untuk membenahi ketertinggalan hukum Islam dan untuk menyesuaikan dengan keadaan aktual harus membuka pintu ijtihad secara bebas tanpa terikat dengan aturan yang telah dikenal di kalangan para mujtahid. Kelompok ini menghendaki perubahan total, dan tidak peduli apakah teks itu adalah al-Qur'an atau Sunnah. Untuk sampai kepada maksud tersebut, mereka sering kali menciptakan berbagai kaidah-kaidah baru. Akan tetapi, upaya penafsirannya sering dianggap sesat—walaupun telah memunculkan corak baru

\footnotetext{
${ }^{2}$ Wahid, Abdurrahman. November, 1987. Fiqh dan Etika Sosial. Aula. No. 09 Tahun IX. Lihat juga Mahfudz, M.A. Sahal. 2003. Fiqh Sosial: Upaya Pengembangan Madzhab Qauli dan Manhaji. Postra: Vol. II. No. 2.
} 
dalam pemikiran hukum Islam — karea tidak mampu memberikan tawaran yang meyakinkan, baik dari segi sumber, metode maupun aplikasinya. ${ }^{3}$

Mereka itulah yang digolongkan sebagai kelompok yang mengutamakan peran akal dalam mengapresiasi dan menjawab realitas konkret. Bahkan mereka berani mengambil jalan sekularistik ketika tidak ada jalan keluar dari ajaran hukum Islam dalam menjawab kebuntuan pemikiran hukum Islam-walaupun sebelumnya telah muncul teori istihsan dan istishlah (mașlahah). Akibatnya, gerakan sekularisasi hukum Islam tidak bisa dibendung, dan terus meluncur yang eksponen utamanya dalam gerakan ini adalah Ali Abd al-Raziq. Karena itu, kelompok ini masuk kategori "pembaru sekularis".

Kedua, sekelompok ahli hukum Islam yang menempatkan teks alQur'an dan Sunnah sebagai pijakan utama dalam menentukan segala aktivitas kehidupannya. Ketentuan-ketentuan teks al-Qur'an dan Sunnah yang jelas dan rinci, dan kitab-kitab karya para ahli hukum Islam tradisional diterima tanpa interpretasi ulang. Karena cara berpikirnya tekstual dan ukuran kebenarannya hanya disesuaikan dengan kehendak Allah (will of God), maka kelompok ini bisa dikategorikan sebagai pemikir "tekstual teosentris" atau tekstual tradisional". Cara berpikir inilah yang diyakini tidak akan mampu memberikan solusi yang memadai dalam menjawab realitas konkret saati ini. sebab, teori interpretasi hukum ini memiliki kesamaan dengan teori interpretasi para ahli hukum Islam (fuqaha'/mujtahid) tradisional walaupun mereka juga telah menerapkan teori nasikh dan mansukh, dan membedakan teks al-Qur'an dan Sunnah yang qath'i dengan yang zhanni, serta yang 'amm dengan yang khas. ${ }^{4}$

Selanjutnya, sejarah perkembangan hukum Islam pada dasarnya adalah perdebatan persoalan peran akal dan wahyu (teks al-Qur'an dan Sunnah) yang telah menjadi perdebatan hangat terutama sejak masa sahabat, yakni antara Umar ibn al-Khaththab dengan para sahabat Nabi lainnya, khususnya mengenai pembagian harta zakat bagi seorang muallaf dan pembagian harta rampasan perang. Dalam hal ini, Umar menolak untuk menerapkan dua ketentuan hukum tersebut, karenanya ketika ia ditentang oleh para sahabat Nabi yang lain, ia mengatakan bahwa pelaksanaan dua ketentuan hukum tersebut sudah hilang relevansinya, sedangkan para penentang Umar justru bersikeras untuk tetap menerapkan dua ketentuan hukum tersebut karena telah diatur secara jelas dan rinci dalam teks al-Qur'an.

Perdebatan peran akal dan wahyu tersebut terus berlanjut di kalangan para ahli hukum Islam, yakni antara Abu Hanifah yang terkenal sebagai tokoh rasionalis yang memunculkan teori istihsan dan penentangnya al-Syafi'i yang terkenal sebagai tokoh tekstual-literalis (baca: qiyas) yang justru menolak

${ }^{3}$ Moh Dahlan, Abdullah Ahmed an-Na'im: Epistemologi Hukum Islam (Yogyakarta: Pustaka Pelajar, 2009), 3-4.

${ }^{4}$ Ibid., 5-7. 
teori istihsan. Perdebatan ini belum selesai sampai di sini, tetapi kemudian disusul dengan penentang berikutnya, yakni al-Shatibi yang memunculkan teori istislah sebagai kritik terhadap teori qiyas. Pada masa masa modern, perdebatan itu dilanjutkan oleh Hasan al-Turabi dengan melakukan pembaruan terhadap ilmu usul figh tradisional. ${ }^{5}$

Sementara itu menurut M. Amin Abdullah pola pembaruan pemikiran hukum Islam dalam kurun waktu klasik hingga kontemporer terbagi menjadi tiga varian yakni, pertama, paradigma literalistik. Paradigma ini sangat dominan pembahasannya tentang teks, dalam hal ini teks berbahasa Arab, baik dari segi grammar maupun sintaksisnya dan mengabaikan pembahasan tentang maksud dasar dari wahyu yang ada dibalik teks literal. Paradigma ini diwakili oleh para ahli usul mazhab mutakalimin (Shafi'iyah, Malikiyah, Hanabilah, dan Mu'tazilah) yang bercorak teologis-deduktif dan mazhab Hanafiyah yang memiliki corak pemikiran induktif-analitis. Paradigma ini berlangsung kurang lebih lima abad (abad ke-2 $\mathrm{H}$ - abad ke-7 H) dan baru mengalami perbaikan dengan munculnya al-Shāțibī (w. 790 H/1388 M) pada abad ke-8 H yang menambahkan teori maquașid al-shariah yang mengacu pada maksud Allah yang paling dasar sebagai pembuat hukum (shari', lawgiver). ${ }^{6}$ Dengan demikian, ilmu usul fiqih tidak lagi hanya terpaku pada literalisme teks. Kehadiran al-Shāțibī sama sekali tidak menghapus paradigma literal, tapi ingin lebih melengkapinya agar ilmu ini dapat lebih sempurna memahami perintah Allah. Dengan demikian, dalam perspektif filsafat ilmu, al-Shāțibī sebenarnya tidak melakukan apa yang menurut Thomas Kuhn disebut dengan pergeseran paradigma (shifting paradigm), tapi lebih hanya melengkapi paradigma lama saja, agar tidak terlalu literalistik. Al-Shātịīi dalam perspektif Kuhn, sesungguhnya tidak melakukan perubahan revolusioner pada bangunan ilmu usul figh.

Kedua, paradigma utilitarianisme. Enam abad kemudian, sumbangan alShāțibī itu direvitalisasi oleh para pembaharu usul fiqih di dunia modern, seperti Muhammad Abduh (w. 1905), Rasyid Ridha (w. 1935), Abdul Wahāb Khallāf (w. 1956), 'Allal al-Fāsi (w. 1973), dan Hasan Turabi. Karena tidak menawarkan teori baru kecuali merevitalisasi prinsip mașlaḥah yang ditawarkan al-Shāțibī melalui teori maqāṣid-nya itu, maka Wael B. Hallaq seperti dikutip oleh M. Amin Abdullah, mengkategorikan para pembaharu di bidang usul dalam kelompok ini sebagai para pembaharu penganut aliran utilitarianisme.

${ }^{5}$ Hasan al-Turabi, Fiqih Demokratis Dari Tradisionalisme Kolektif Menuju Modernisme Populis (Bandung: Arasy, 2003), 5-57.

${ }^{6}$ Lihat selanjutnya karya al-Shātịīi, Abū Ishāq Ibrāhīm al-Lakhmī. Tanpa Tahun.

$A l$ Muwāfaqat fì Ușūl al-Aḥkām. Beirut: Dār al-Fikr.

${ }^{7}$ M. Amin Abdullah, Paradigma Alternatif Pengembangan Ushul Fiqh dan Dampaknya pada Fiqh Kontemporer, dalam Ainurrofiq (ed.). "Mazhab Jogja” Menggagas Paradigma Ushul 
Ketiga, paradigma liberalisme. Sementara itu, pertanyaan tentang bagaimanakah teks suci dapat dipahami dan kemudian dijalankan dalam konteks dunia modern yang sudah barang tentu tidak lagi sama dengan konteks zaman Nabi tetap saja masih menjadi agenda besar bagi umat Islam dewasa ini. Pertanyaan semacam ini menurut sebagian pakar seperti Muhammad Iqbal, Mahmud Muhammad Taha, Abdullah Ahmed al-Naim, Muhammad Said Ashmawi, Fazlur Rahman, dan Muhammad Syahrur sama sekali tidak dapat diselesaikan dengan berpijak pada prinsip mașlahah klasik di atas. Bahkan mereka beranggapan bahwa prinsip maslahah tidak lagi memadai untuk membuat hukum Islam mampu hidup di dunia modern. Dengan mengambil sample tiga orang pemikir (Ashmawi, Fazlur Rahman dan Syahrur), Hallaq menamakan kelompok ini dengan aliran liberalisme keagamaan (religious liberalism), karena coraknya yang liberal dan cenderung membuang teori-teori usul fiqih lama. Menurut Hallaq upaya pembaharuan di bidang usul dari kelompok kedua ini dianggapnya lebih menjanjikan dan lebih persuasif. Kelompok ketiga ini dalam membangun metodologinya yang ingin menghubungkan antara teks suci dan realitas dunia modern lebih berpijak pada upaya melewati makna eksplisit teks untuk menangkap jiwa dan maksud luas dari teks. ${ }^{8}$

\section{Abdurrahman Wahid: Biografi dan Tipologi Pemikiran}

Abdurrahman Wahid atau yang lebih dikenal dengan Gus Dur adalah putra dari pasangan K.H Abdul Wahid Hasyim dan Solichah. Terlahir dengan nama Abdurrahman ad-Dakhil (Sang Penakluk), Gus Dur dilahirkan di Jombang pada 4 Agustus 1940. ${ }^{9}$ Dalam dirinya mengalir darah biru Kiai-Kiai besar Nusantara yakni K.H. Hasyim Asy'ari dan K.H. Bisri Syansuri yang merupakan para pendiri jamiyah Nahdlatul Ulama (NU).

Gus Dur menghabiskan sebagian masa dewasanya di pesantren dan di perkuliahan. Seperti para ulama besar di zaman klasik, Gus Dur menjadi seorang pengembara (ghuraba') pencari ilmu dari satu pesantren ke pesantren lainnya. Di Yogyakarta, ia menjadi santri kalong dan mengaji kepada K.H. Ali Maksum yang dikenal sebagai Kiai yang humanis dan egaliter. ${ }^{10}$ Dari beliau, Gus Dur belajar

Fiqh Kontemporer, (Djogjakarta: Ar-Ruzz Media-Fakultas Syariah IAIN Sunan Kalijaga, 2002), 119-120.

${ }^{8}$ Ibid., 122.

${ }^{9}$ Greg Barton, Biografi Gus Dur The Authorized Biography of Abdurrahman Wahid, terj. Lie Hua Yogyakarta: LKiS, 2003), 25.

${ }^{10}$ Abdul Wahid Hasan, Gus Dur Mengarungi Jagad Spiritual Sang Guru Bangsa (Yogyakarta: IRCiSoD, 2015), 130. 
memahami arti dan eksistensi manusia di dunia ini. Kiai Ali Maksum mengajari Gus Dur bagaimana menjadi "manusia yang memanusiakan manusia"."1

Kiai kharismatik lain yang ikut membentuk kepribadian Gus Dur adalah K.H. Chudlori, pengasuh pondok pesantren Tegalrejo Magelang. Kiai Chudlori dikenal sebagai seorang Kiai yang memiliki wawasan spiritualitas yang mumpuni. Kiai Chudlori mengajari Gus Dur akan luasnya dunia spiritualitas yang tanpa batas. Kiai Chudlori juga menanamkan kepada Gus Dur bagaimana menyelami budaya dan kearifan lokal (local wisdom) masyarakat Nusantara. ${ }^{12}$ Setelah puas mengenyam dunia pendidikan di pesantren, Gus Dur melanjutkan pendidikannya di Mesir dan Baghdad. Di Mesir, Gus Dur bergelut dan bergumul dengan realitas sosio-kultur masyarakat setempat. Ia mendalami berbagai aliran dan paham keislaman yang ada di sana. Dari pengakuannya sendiri, ia mempelajari secara mendalam berbagai paham keislaman mulai dari Ikhwanul Muslimin, Marxis, Sosialisme Arab hingga fundamentalis. ${ }^{13}$

Dalam konteks pembaruan hukum Islam di Indonesia Gus Dur juga menyoroti mengenai hal ini melalui perlunya bermazhab secara metodologi (manhaji). Gus Dur menginginkan agar umat Islam tidak hanya terpaku pada teks-teks klasik yang dirumuskan oleh para ulama agung di era awal Islam saja. Akan tetapi, lebih dari itu umat Islam harus berani melakukan terobosanterobosan baru—dengan cara manhaji-mengingat umat Islam saat ini hidup di era global yang sarat dengan problematika sosial yang tentu berbeda dengan yang dihadapi oleh para ulama klasik tersebut. Dalam memetakan sebuah pemikiran dapat dilihat dari perspektif apa yang digunakan, atau didasarkan pada pola pemahaman masyarakat (ulama khususnya) terhadap sumber ajaran (agama) dalam kaitannya dengan fakta sosial yang melingkupinya.

Ahmad Arifi dalam bukunya Pergulatan Pemikiran Fiqih "Tradisi" Pola Mą̧hab misalnya, memotret dinamika pemikiran keagamaan berdasarkan pemetaan yang dibuat John L. Esposito dengan tiga kategori, yaitu ${ }^{14}$ pertama, restriction of traditionalist merupakan pola pemikiran keagamaan tradisional yang sempit. Pemikiran ini sangat dipengaruhi oleh tradisi pemikiran ulama masa lampau, di mana hasil pemikiran ulama terdahulu dijadikan acuan dan sekaligus referensi final bagi setiap persoalan kemasyarakatan yang muncul pada saat sekarang. Dengan kata lain, mereka hanya meng-copy paste apa yang sudah ada

\footnotetext{
${ }^{11}$ Ibid., 130.

${ }^{12}$ Rohani Shidiq, Gus Dur Penggerak Dinamisasi Pendidikan Pesantren Memperteguh Nilai-Nilai Pesantren bagi Transformasi dan Kosmopolitanisme Islam Nusantara (Yogyakarta: Istana Publishing, 2015), 11.

${ }^{13}$ Munawar Ahmad, Ijtihad Politik Gus Dur Analisis Wacana Kritis (Yogyakarta: LKiS, 2010), 91.

${ }^{14}$ Ahmad Arifi, Pergulatan Pemikiran Fiqih "Tradisi” Pola Mazhab (Yogyakarta: eLSAQ Press, 2010), 257.
} 
dari warisan ulama masa lalu. Pola pemikiran yang demikian ini biasanya diikuti oleh komunitas masyarakat tradisional yang membanggakan tradisi, seperti kelompok pengikut pola bermazhab dalam keagamaan. NU dalam hal ini termasuk di dalamnya.

Kedua, modernist scripturalism adalah tipe pola gerakan yang menamakan dirinya kelompok modern. Pola ini menggunakan pemahaman keagamaan secara tekstual dari ajaran-ajaran suci. Dengan demikian, kelompok ini terpaku pada pemahaman doktrin secara tekstual dengan merujuk nas secara redaksional, tidak pada inti ajaran yang menjadi maqāșid al-sharīah. Justifikasi terhadap tindakan (amalan) agama dilihat pada ada atau tidaknya referensi tekstual nas. Amalan agama dianggap benar ketika ketika ada dalil dari nas secara tersurat (eksplisit). Dapat dimasukkan dalam kategori ini adalah Muhammadiyah dan Persatuan Islam (Persis) di Indonesia, yang dipengaruhi oleh gerakan tajdid (purifikasi) kaum Wahabi di Arab Saudi.

Ketiga, socio-bistorical approach adalah tipe pola pemahaman keagamaan yang dalam melihat ketentuan-ketentuan ajaran agama (naș) lebih didasarkan kepada aspek-aspek historis dan konteks sosial yang berkembang di masyarakat. Kelompok ini, menurut Esposito, merupakan kelompok yang diidolakan untuk mempersiapkan masyarakat Muslim modern atau neo-modern. Di antara contoh dari model pemikiran ini adalah pemikiran Fazlur Rahman, Nurcholish Madjid dan Abdurrahman Wahid (Gus Dur).

Pemetaan (mapping) ketiga kategori pemikiran keagamaan tersebut dapat dilihat pada tabel di bawah ini:

\begin{tabular}{|l|l|l|l|}
\hline No & Kategori & Pengertian & Lembaga/Pemikir \\
\hline 1. & $\begin{array}{l}\text { Restriction of } \\
\text { Traditionalist }\end{array}$ & $\begin{array}{l}\text { Pemahaman terhadap } \\
\text { tradisi pemikiran ulama } \\
\text { masa lampau sebagai } \\
\text { referensi final } \\
\text { - Masyarakat tradisional }\end{array}$ & $\begin{array}{l}\text { Nahdlatul Ulama } \\
\text { (NU) }\end{array}$ \\
\hline 2. & $\begin{array}{l}\text { Modernist } \\
\text { Scripturalism }\end{array}$ & $\begin{array}{l}\text { Pemahaman secara } \\
\text { tekstual-redaksional } \\
\text { terhadap ajaran-ajaran } \\
\text { suci }\end{array}$ & $\begin{array}{l}\text { Muhammadiyah } \\
\text { dan Persis } \\
\text { Pasyarakat perkotaan }\end{array}$ \\
\hline 3. & $\begin{array}{l}\text { Pocio-Historical } \\
\text { Approach }\end{array}$ & $\begin{array}{l}\text { Pemahaman teks kepada } \\
\text { aspek-aspek historis dan } \\
\text { konteks sosial }\end{array}$ & $\begin{array}{l}\text { Fazlur Rahman, } \\
\text { Nurcholish Madjid } \\
\text { dan Abdurrahman } \\
\text { Wahid. }\end{array}$ \\
\hline
\end{tabular}


Dari pemetaan tersebut terlihat bahwa pemikiran keagamaan Abdurrahman Wahid memiliki perbedaan yang signifikan dengan dua model pemikiran keagamaan yang lain. Perbedaan ini terlihat pada keberpihakannya terhadap ilmu-ilmu sosial modern dalam menafsirkan teks-teks keislaman dari warisan pemikiran ulama klasik. Dengan demikian terjadi dialog antara teks-teks keislaman klasik dan konteks sosial masyarakat kontemporer yang dicirikan dengan pendekatan teori-teori sosial kritisnya yang memiliki dimensi pembebasan dari berbagai ketidakadilan sosial dan diskriminasi dalam kehidupan.

\section{Pemikiran Mașlaḥah Berbasis Etika Gus Dur}

Dalam perspektif Karl Mannheim lahirnya sebuah pemikiran, ide, dan gagasan tidak dapat dilepaskan dari situasi dan kondisi serta realitas sosial sang pemikir tersebut. Dengan kata lain, lahirnya sebuah ide dan gagasan merupakan akibat logis dari adanya proses dialektika antara aktifitas berpikir sang pemikir dengan realitas obyektif disekitarnya. Teori yang dimunculkan oleh Mannheim ini dikenal dengan nama teori relasional. ${ }^{15}$

Mengacu pada teori tersebut, termasuk dalam hal ini adalah pemikiran mașlaḥah Abdurrahman Wahid (Gus Dur). Di zaman Orde Baru, Gus Dur dikenal sebagai seorang pemikir Islam yang kritis terhadap kungkungan dan hegemoni kekuasan. Gus Dur menjadi trademark dari gerakan civil society yang gigih dalam melakukan proses pemberdayaan dan penyadaran umat.

Dalam bukunya Islamku Islam Anda Islam Kita Agama Masyarakat Negara Demokrasi Gus Dur menegaskan:

"Orientasi paham keislaman sebenarnya adalah kepentingan orang kecil dalam hampir seluruh persoalannya. Lihat saja kata "mașlahah 'àmmab", yang berarti kesejahteraan umum. Inilah sebenarnya yang menjadi objek dari segala macam tindakan yang diambil pemerintah. Kata kesejahteraan umum dan/atau kemaslahatan umum itu tampak nyata dalam keseluruhan umat Islam. Yang langsung tampak, umpamanya, adalah kata kunci dalam adagium fiqh: "tindakan atau kebijakan seorang pemimpin atas rakyat (yang dipimpin) sepenuhnya bergantung kepada kebutuhan/kesejahteraan mereka (tașarruf alimàm 'ala al-ra'iyyah manuțun bi al-mașlahah)." Adapun yang tidak langsung mengenai kebutuhan orang banyak dapat dilihat dalam adagium lain: "menghindarkan kerusakan/kerugian diutamakan atas upaya membawakan keuntungan/kebaikan (dar'u al-mafäsid muqaddamun ala jalbi al-mașälih)." Artinya, menghindari hal-hal yang merusak umat lebih diutamakan atas upaya

\footnotetext{
${ }^{15}$ Karl Mannheim, Ideologi dan Utopia: Menyingkap Kaitan Pikiran dan Politik (Ideology and Utopia an Introduction to the Sociology of Knowledge), terj. F. Budi Hardiman (Yogyakarta: Kanisius, 1991), 222.
} 
membawakan kebaikan bagi mereka. Dengan demikian, menghindari kerusakan dianggap lebih berarti daripada mendatangkan kebaikan. ${ }^{16}$

Teks di atas menggambarkan bahwa pemikiran atau pendekatan mașlaḥah yang diinisiasi Gus Dur menjadi penting untuk dikembangkan di era kontemporer. Sekaligus dapat menjadi alternatif pendekatan, khususnya bagi umat Islam dalam merawat masa depan Islam di Indonesia yang harus berhadapan dengan tantangan modernitas dan globalisasi. ${ }^{17}$

Di era kontemporer ini penetapan dan perumusan hukum Islam melalui pendekatan maṣlahah memiliki tingkat relevansi yang tidak diragukan keabsahannya. Pendekatan mașlaḥah diharapkan bisa menumbuhkan pola pikir dan cara pandang baru dalam mencermati problematika kemasyarakatan yang muncul demikian pesatnya di era globalisasi ini. ${ }^{18}$

Pendekatan mașlaḥah Gus Dur yang bersifat induktif-empirik kiranya dapat dijadikan sebagai salah satu alternatif dalam memecahkan persoalanpersoalan umat dan kebangsaan. Dikatakan induktif-empirik karena pendekatan tersebut berangkat dari realitas persoalan keumatan di sekitarnya yang kemudian disikapi dengan arif dan bijak (wise) sesuai dengan tradisi yang berkembang di masyarakat. ${ }^{19}$ Dengan pendekatan maṣlahah yang berlandas tumpu pada persoalan riil dalam masyarakat ini Gus Dur sebenarnya ingin menunjukkan bahwa Islam adalah agama yang memiliki watak transformatif dan membawa misi rahmatan li al-'álamin.

Dalam konteks Indonesia, terdapat kasus-kasus kekerasan intelektual yang menimpa beberapa intelektual muda Islam misalnya Ulil Abshar Abdalla. Kasus intimidasi (baca: kekerasan intelektual).yang menimpa Ulil tersebut dikarenakan keberanian intelektualnya dalam menawarkan ide-ide dan gagasan pembaruan Islam di Indonesia. ${ }^{20}$ Merespons kasus tersebut, Gus Dur tampil

\footnotetext{
${ }^{16}$ Abdurrahman Wahid, Islamku Islam Anda Islam Kita Agama Masyarakat Negara Demokrasi, (Jakarta: The Wahid Institute, 2006), 21-22.

${ }^{17}$ Abdurrahman Wahid, Islam di Asia Tenggara, dalam Abu Zahra (Ed.), Politik Demi Tuhan Nasionalisme Religius di Indonesia, (Bandung: Pustaka Hidayah, 1999), 195-198.

${ }^{18}$ Mahfudh, M.A. Sahal. 2014. Mengaktualkan Fiqh Klasik di Era Global. Dalam Munawir Aziz (Ed.). Epistemologi Fiqh Sosial Konsep Hukum Islam dan Pemberdayaan Masyarakat, xvi. Purworejo Margoyoso Pati Jawa Tengah: Fiqh Sosial Institute Kampus STAI Mathali'ul Falah. Bandingkan dengan Abubakar, Al-Yasa', 2016, Metode Istislahiah Pemanfaatan Ilmu Pengetahuan dalam Ushul Fiqh. Jakarta: Prenada Media Group.

${ }^{19}$ Lihat Wahid, Abdurrahman. 2007. Penafsiran Kembali Ajaran Agama: Dua Kasus dari Jombang. Dalam Agus Maftuh Abegebriel dan Ahmad Suaedy (Eds.), Islam Kosmopolitan Nilai-nilai Indonesia dan Transformasi Kebudayaan, Jakarta: The Wahid Institute, 71-78.

${ }^{20}$ Dzulmanni (ed.), Islam Liberal dan Fundamentalisme Sebuah Pertarungan Wacana (Yogyakarta: eLSAQ Press, 2005), 7-16.
} 
sebagai garda depan membela hak-hak kebebasan individu dalam mengeluarkan ide dan gagasan pembaruan. Dalam pandangan Gus Dur aksi kekerasan yang ditunjukkan sekelompok golongan tertentu tersebut dinilai sangat merugikan perkembangan peradaban Islam ke depannya. Kekerasan memang hampir mustahil dihilangkan dari panggung sejarah kemanusiaan umat manusia karena terkait dengan perebutan dan perkelahian pemaknaan terhadap nilai agung yang bernama "kebenaran". Terkait hal ini Gus Dur menyatakan:

"Padahal, sikap seperti itulah yang membunuh sejarah, karena sebenarnya sejarah memiliki perkembangan sendiri. Sedangkan kebenaran Ilahi selamanya di luar sejarah, sehingga tugas kita untuk mempertaruhkan kebenaran tersebut amatlah berat, dan kita tidak bisa main hantam. Bagaimana kita bisa "mempertahankan" kebenaran itu, sementara kita adalah manusia yang memiliki kelemahan-kelemahan fatal? Kita juga jangan pernah lupa, meskipun memikul tugas untuk "mempertahankan" kebenaran Ilahi itu, pada saat yang sama kita harus menjunjung tinggi perikemanusiaan. Pada spektrum ini kemutlakan hanyalah milik kebenaran Ilahi, sedangkan kita dituntut memiliki kemampuan untuk mempertahankan kemanusiaan. Di sinilah terjadi proses "tarik ulur" antara dua hal yang sama-sama mewarnai kehidupan manusia: kemutlakan kebenaran Ilahi dan reletivitas kemampuan manusia. Selanjutnya terjadilah gerak dinamis yang tidak berkesudahan, bagaimana manusia mempertahankan keyakinannya, namun di sini yang lain dituntut mengakui kenyataan." ${ }^{21}$

Teks di atas menggambarkan bagaimana corak epistemologi mașlaḥah yang coba dikembangkan oleh Gus Dur. Dalam teks tersebut terdapat dua sisi kebenaran yang selalu diperebutkan oleh umat manusia. Di satu sisi, kebenaran mutlak Ilahi merupakan tumpuan dari seluruh pengabdian umat manusia pada Tuhan. Kebenaran ini menurut Gus Dur bersifat abstrak, karena berada di luar sejarah manusia dan tidak jarang melahirkan klaim-klaim kebenaran sepihak antara umat satu dengan lainnya. Sementara di sisi lain, terdapat "kebenaran" relatif yang diyakini oleh umat manusia melalui penalarannya yang sangat serba terbatas.

Kebenaran mutlak Ilahi dalam hal ini, jika ditinjau dari perspektif teologis maka akan melahirkan corak pemikiran yang bersifat teosentris karena ia menempatkan peran serba Tuhan pada tingkat yang paling tinggi. Pada titik ini, segala bentuk penafsiran akan tercurah dan terpaku pada dimensi

\footnotetext{
${ }^{21}$ Abdurrahman Wahid, Sejarah Kekerasan yang Selalu Berulang, dalam Tri Agus S. Siswowiharjo, Marto Art dan Mathori A Elmawa (eds.), Sekedar Mendahului Bunga Rampai Kata Pengantar (Bandung: Nuansa, 2011), 285-286.
} 
tekstualitas-normativitas agama. Model pemahaman seperti ini pada akhirnya melahirkan corak pemikiran maslahah yang bersifat teosentris (mașlahah alIlähiyyab). Sementara itu, kebenaran yang selalu berpihak pada nilai-nilai kemanusiaan akan melahirkan corak pemikiran mașlaḥah yang bersifat antroposentris (mașlahahal-insāniyyah).

Dalam kaitannya dengan pendekatan mașlaḥah ini, dari berbagai tulisannya sepertinya ia memang tidak membangun sebuah konsep mașlahahah yang betul-betul bisa dikatakan baru. ${ }^{22}$ Akan tetapi dapat ditegaskan di sini, dengan menganalisis berbagai tulisannya pula didapatkan satu kesimpulan bahwa gagasan-gagasan dan idenya syarat dengan muatan-muatan dan nilai-nilai mașlaḥah di dalamnya. ${ }^{23}$ Pendekatan mașlaḥah yang digagasnya berangkat dari pengalaman empirik yang dilaluinya ketika menimba khazanah ilmu keislaman baik di pesantren-pesantren, di Timur Tengah maupun ketika bersentuhan dengan ideologi-ideologi sekuler Barat.

\section{Pemikiran Etika Utilitarianisme}

Pada umumnya pandangan-pandangan mengenai etika yang berkembang di dunia ini dikelompokkan menjadi tiga, yaitu etika hedonistik, utilitarian, dan deontologis. Hedonisme mengarahkan etika kepada keperluan untuk menghasilkan sebanyak-banyaknya kesenangan bagi manusia. Etika utilitarianistik mengoreksinya dengan menambahkan bahwa kesenangan atau kebahagiaan yang dihasilkan oleh suatu etika yang baik adalah kebahagiaan bagi sebanyak mungkin orang dan bukan kesenangan atau kebahagiaan individual. Sementara etika deontologis memandang bahwa sumber sebagai perbuatan etis adalah rasa kewajiban. Maka aliran ini mempercayai bahwa sikap etis bersifat fitri dan pada saat yang sama tidak murni rasional. Pada kenyataannya, hasil

${ }^{22}$ Indikasi ini diperkuat dalam berbagai artikel yang ditulisnya yang mencerninkan perluasan dari makna maqāssid al-sharīah yang dirumuskan oleh para ulama klasik. Lihat dalam Frans M. Parera dan T. Jakob Koekerits (eds.), Gus Dur Menjawab Perubahan Zaman Warisan Pemikiran K.H. Abdurrahman Wahid, (Jakarta: PT Kompas Media Utama, 2010), 14-18. Lihat dalam artikelnya yang berjudul Islam dan Hubungan Antarumat Beragama di Indonesia. Lihat juga Mawardi, Ahmad Imam. 2010. Fiqih Minoritas, Fiqh Al-Aqalliyyat dan Evolusi Maqashid al-Shari'ah dari Konsep ke Pendekatan. Yogyakarta: LKiS. Kholish, M. Anas, dan Salam, Nor, 2015, Epistemologi Hukum Islam Transformatif Sebuah Tawaran Metodologis dalam Pembacaan Kontemporer, Malang: UIN-Maliki Press.

${ }^{23}$ Untuk menyebut beberapa contoh lihat artikel-artikel yang ditulisnya dalam buku Islam Ku Islam Anda Islam Kita (1) Islam dan Kesejahteraan Rakyat, 176-179. (2) Ekonomi Ditata dari Orientasinya, 205-208). (3) Benarkah Harus Ada Konsepnya? , 209-212 dan lain-lain. 
pemikiran filosof tentang etika sering merupakan irisan atau bahan dasar dari ketiga aliran besar itu. ${ }^{24}$

Menurut Frans Magnis Suseno utilitarianisme dapat dirumuskan dengan "tindakan atau peraturan tindakan yang secara moral dianggap betul adalah yang paling menunjang kebahagiaan semua yang bersangkutan" atau bertindaklah sedemikian rupa sehingga akibat tindakannya menguntungkan bagi semua yang bersangkutan". Jadi utilitarianisme lebih mementingkan pada akibat dari suatu perbuatan. Ini berbeda dengan deontologis yang lebih mementingkan pada suatu esensi tindakan moral tersebut, tanpa mempertimbangkan akibat tindakannya. ${ }^{25}$

Doktrin utilitarianisme berkembang pesat di Inggris pada abad XIX. Sebagai aliran dalam filsafat, utilitarianisme (utilitarianism) dipahami sebagai pandangan tentang sebuah tindakan yang secara moral dapat benar atau salah tergantung dari konsekuensi tindakannya untuk kebahagiaan manusia. Secara moral suatu tindakan akan dikatakan benar jika; (1) menghasilkan lebih banyak kebaikan daripada kejahatan dibanding tindakan lain yang dapat diambil; (2) menghasilkan sebanyak mungkin kebaikan di dunia dibanding tindakan lain yang mungkin diambil dalam situasi dan kondisi yang sama. Jadi ukuran dari harkat atau nilai moral dari tindakan dinilai berdasarkan kebaikan dan keburukan yang diakibatkannya. Tindakan moral yang dibenarkan adalah tindakan yang didasarkan pada peraturan moral yang menghasilkan akibat-akibat yang lebih baik dan menyenangkan. ${ }^{26}$

Teori kemanfaatan hukum Barat dipelopori oleh Jeremy Bentham (1748-1832), seorang filsuf, ekonom, yuris, dan reformer hukum, yang memiliki kemampuan untuk menenun dari benang "prinsip kegunaan" (utilitas) menjadi dasar doktrin etika dan ilmu hukum yang luas. Prinsip utility dikemukakan oleh Bentham dalam karya monumentalnya tahun 1789, "Introduction to the Principles of Morals and Legislation". Di dalam karyanya tersebut Bentham mendefinisikan kemanfaatan sebagai sifat dalam segala benda yang dengannya, benda tersebut cenderung mendapatkan kesenangan, kebaikan atau kebahagiaan, atau untuk mencegah terjadinya kerusakan, penderitaan, atau kejahatan serta ketidakbahagiaan pada pihak yang kepentingannya dipertimbangkan. Menurut Bentham, alam telah menempatkan manusia di bawah pengaturan dua penguasa yang berdaulat, yaitu penderitaan (pain) dan kegembiraan (pleasure). Keduanya menunjukkan apa yang harus kita lakukan dan menentukan apa yang akan kita lakukan. Fakta bahwa kita menginginkan kesenangan dan berharap untuk

\footnotetext{
${ }^{24}$ Lihat Pengantar Haidar Bagir "Etika "Barat", Etika Islam" dalam M. Amin Abdullah Antara Al-Ghazali dan Kant: Filsafat Etika Islam (Bandung: Mizan, 2002), 15.

${ }^{25}$ Franz Magnis Suseno, 13 Tokoh Etika (Yogyakarta: Kanisius, 1997), 178.

${ }^{26}$ Biyanto, Filsafat Ilmu dan Ilmu Keislaman, (Yogyakarta: Pustaka Pelajar, 2015), 264-265.
} 
menghidari penderitaan, digunakan oleh Bentham untuk membuat keputusan, bahwa kita harus mengejar kesenangan. ${ }^{27}$

Pemikiran berikutnya adalah John S. Mill dan Rudolf von Jhering. Jika utilitarianisme Bentham dikenal sebagai utilitarianisme individu, maka utilitarianisme Mill lebih bernuansa psikologis dan utilitarianisme Jhering dikenal sebagai utilitarianisme sosial. Mill (1806-1873) menjelaskan konsep utilitarianisme psikologisnya dengan menghubungkan kebahagiaan manusia dan nafsu. Tujuan manusia adalah kebahagiaan dan manusia mengupayakan kebahagiaan itu lewat hal-hal yang membangkitkan nafsunya. Tujuan kehidupan manusia adalah kebahagiaan in se bukan kebahagiaan dalam benda. Utilitarianisme Mill sesungguhnya menolak pendapat Bentham yang mengatakan bahwa tidak ada pertentangan antara kepentingan individu dan kepentingan umum. Mill berpendapat bahwa tindakan manusia hendaknya dilakukan sedemikian rupa agar dapat menyesuaikan keuntungan dengan kepentingan bersama.

Mill memulai teori etikanya dengan merumuskan prinsip kegunaan: "suatu tindakan harus dianggap betul dan bermoral jika mendatangkan kebahagiaan, yaitu kesenangan (pleasure) dan kebebasan dari perasaan sakit. Namun yang dimaksudkan dengan kenikmatan adalah bukan sebatas kenikmatan jasmani, tetapi karena kenikmatan rohani adalah lebih luhur dan mulia. Demi nikmat luhur (rohani), seperti nikmat estetis dan kebijaksanaan, seseorang boleh meninggalkan nikmat yang lebih rendah. Ia mengatakan dalam jargonnya: "lebih baik menjadi manusia yang tidak puas daripada babi yang puas, lebih baik menjadi Sokrates yang puas, daripada seorang tolol yang puas". ${ }^{28}$

Jhering (1818-1892) dengan utilitarianisme sosialnya, menjelaskan bahwa tujuan hukum harus selalu dihubungkan dengan kepentingan sosial. tujuan hukum adalah melidungi kepentingan-kepentingan yang ditandai oleh upaya memperoleh kebahagiaan dan kemanfaatan (seperti Bentham), tetapi kepentingan individu mesti dipahami sebagai dan dijadikan bagian dari tujuan sosial yang selalu berkaitan dengan kepentingan orang lain. ${ }^{29}$

Kesimpulan dari pendapat-pendapat di atas adalah bahwa teori utilitarianisme memberi penekanan pada dua hal penting, yakni hukum dan tujuan dari hukum tersebut. Hukum, dalam teori ini bukan dipahami sebagai hukum dalam tataran filosofis atau das sollen tetapi hukum positif, sementara

\footnotetext{
${ }^{27}$ Warkum Sumitro, Moh. Anas Kholish dan Labib Muttaqin, Hukum Islam dan Hukum Barat Diskursus Pemikiran dari Klasik hingga Kontemporer (Malang: Setara Press, 2017), 95-97.

${ }^{28}$ Moh Roy Purwanto, Dekonstruksi Teori Hukum Islam Kritik terhadap Konsep Mashlahah Najmuddin al-Thufi (Yogyakarta: Kaukaba, 2014), 268.

${ }^{29}$ Warkum Sumitro, Moh. Anas Kholish dan Labib Muttaqin, Hukum Islam dan Hukum Barat, 97-98.
} 
tujuan hukum terutama dikaitkan dengan manfaat yang diperoleh dari hukum itu, yakni kebahagiaan dan kesejahteraan sebanyak mungkin individu atau masyarakat (the greatest happiness for the greatest number of the people).

Prinsip-prinsip pemikiran yang dikembangkan oleh mazhab utilitarianisme tersebut juga diapresiasi oleh Gus Dur. Salah satu ide dan gagasannya yang bersentuhan dengan hal ini adalah keberpihakan dan perlindungannya terhadap kaum minoritas di Indonesia. Dan hal ini direalisasikannya dengan mengabsahkan aliran Konghucu sebagai salah satu agama resmi dan diakui di Indonesia. Dalam konteks Indonesia sebagai negara bangsa yang multikultural, Gus Dur merangkul semua pihak, baik kalangan mayoritas maupun mioritas. Ini sekaligus menjadi bukti bahwa orientasi pemikirannya adalah kemaslahatan publik (maslahat al-'ammah).

Berdasarkan teori etika ini, konsep mașlaḥah Gus Dur mendapatkan dukungan teoritis. Kemaslahatan yang bagi Gus Dur merupakan tujuan utama pensyariatan, sesuai dengan teori etika Mill atau Jhering bahwa sesuatu yang dianggap paling baik adalah yang memberikan manfaat (utility) atau mașlaḥah bagi masyarakat luas tanpa terkecuali.

\section{Perbandingan Pemikiran Maṣlaḥah Berbasis Etika dan Etika Utilitarianisme}

Dengan penjelasan di atas pemikiran mașlaḥah berbasis etika Gus Dur jika dikomparasikan dengan pemikiran etika utilitarianisme dapat digambarkan sebagai berikut:

\begin{tabular}{|c|c|c|c|}
\hline No & $\begin{array}{l}\text { Pemikiran } \\
\text { Mașlaḥah } \\
\text { Berbasis Etika } \\
\text { Gus Dur }\end{array}$ & $\begin{array}{l}\text { Tujuan dan } \\
\text { Keberpihakan }\end{array}$ & Metode Pendekatan \\
\hline 1. & $\begin{array}{l}\text { Konsep } \\
\text { Mașlahah Gus } \\
\text { Dur } \\
\text { (Substantif- } \\
\text { Inklusif- } \\
\text { antroposentris) }\end{array}$ & $\begin{array}{l}\begin{array}{l}\text { Kepentingan } \\
\text { golongan } \\
\text { (agama, }\end{array} \\
\text { suku, aliran dan } \\
\text { golongan) } \\
\text { mayoritas maupun } \\
\text { minoritas, terutama } \\
\text { kalangan minoritas } \\
\text { yang tertindas }\end{array}$ & $\begin{array}{l}\text { Kepentingan Umum/ } \\
\text { Publik (mașlahah al- } \\
\text { 'ämmah) berdasarkan } \\
\text { nilai-nilai universal Islam } \\
\text { (maqāșid al-shariah), } \\
\text { sosiologis-historis- } \\
\text { kultural, teori hukum } \\
\text { Islam (legal theory) dan } \\
\text { kaidah-kaidah hukum } \\
\text { Islam (legal maxims) }\end{array}$ \\
\hline 2. & Utilitarianisme & $\begin{array}{l}\text { Kebahagiaan orang } \\
\text { banyak, sementara } \\
\text { kepentingan dan }\end{array}$ & $\begin{array}{l}\text { Rasionalitas } \\
\text { approach) }\end{array}$ \\
\hline
\end{tabular}




\begin{tabular}{|l|l|l|}
\hline & $\begin{array}{l}\text { perlindungan } \\
\text { minoritas kurang } \\
\text { mendapat perhatian }\end{array}$ & \\
\hline
\end{tabular}

Dari gambaran tabel di atas terlihat sisi-sisi persaman dan perbedaan antara pemikiran mașlaḥah berbasis etika Gus Dur dengan etika utilitarianisme. Persamaan keduanya terlihat pada tataran teorisasi bahwa ukuran segala sesuatu dilihat dari segi kegunaan dan kemanfaatannya. Dalam konsep utilitarinisme Bentham ukuran kegunaan dan kemanfaatan diukur hanya sebatas kenikmatan jasmani atau lahiriyah semata dan bersifat individual.

Pada titik inilah Gus Dur mengambil jalan berbeda dengan mazhab utilitarianisme yang digagas Bentham tersebut. Kemanfaatan atau kegunaan (utility) dari sesuatu haruslah dapat dinikmati oleh mayoritas masyarakat dan tidak hanya oleh segelintir individu atau kelompok tertentu. Dalam ranah yang agak subtil Gus Dur pun juga mengambil pilihan berbeda dengan konsep yang digagas John. S. Mill. Jika Mill menekankan kemanfaatan bagi sebanyak mungkin orang dengan kurang peduli dengan kebahagiaan individu atau sekelompok golongan, maka Gus Dur sebaliknya, tetap berupaya agar kebahagiaan itu tetap bisa dirasakan oleh kalangan mayoritas dan minoritas masyarakat.

Sementara itu pemikiran mașlaḥah yang digagasnya jika ditinjau dari sisi epistemologi hukum Islam lebih mendekati kepada model komparasi dari berbagai pemikiran maṣlaḥah yang dirumuskan oleh para ulama klasik. Lebih dari itu, Gus Dur telah mengubah orientasi maslahah klasik yang bersifat individual (mașlahah al-khäșab) ke maslahah yang berorientasi sosialkemasyarakatan (mașlahah al'ámmab). Hal ini terlihat dari pemikiran keislaman yang digagasnya di wilayah publik seperti status dan peranan perempuan di wilayah publik, keluarga berencana (family planning), dialog antar agama dan Pancasila sebagai asas dan dasar negara dan sebagainya. ${ }^{30}$

Dari penjelasan di atas pendekatan mașlaḥhah berbasis etika (mașlaḥa based ethics) Gus Dur dapat dilihat dalam pemetaan (mapping) berikut:

\footnotetext{
${ }^{30}$ Lihat Abdurrahman Wahid, Kumpulan Kolom dan Artikel Abdurrahman Wahid Selama Era Lengser (Yogyakarta: LKiS, 2002). Abdurrahman Wahid, Pergulatan Negara, Agama, dan Kebudayaan (Jakarta: Desantara 2001). Einar Martahan Sitompul, NU dan Pancasila Yogyakarta: LKiS, 2010). Syaiful Arif, Humanisme Gus Dur Pergumulan Islam dan Kemanusiaan, (Yogyakarta: Ar-Ruz Media, 2013).
} 


\begin{tabular}{|c|c|c|c|c|}
\hline Nama Tokoh & $\begin{array}{l}\text { Latar } \\
\text { Belakang } \\
\text { Pemikiran }\end{array}$ & $\begin{array}{l}\text { Klasifikasi } \\
\text { Mașlaḥah }\end{array}$ & $\begin{array}{l}\text { Cara } \\
\text { Mengetahui } \\
\text { Mașlaḥah }\end{array}$ & $\begin{array}{l}\text { Fungsi } \\
\text { Mașlaḥah }\end{array}$ \\
\hline $\begin{array}{l}\text { Abdurrahman } \\
\text { Wahid } \\
\text { (Gus Dur) } \\
\text { 1940-2009 M }\end{array}$ & $\begin{array}{l}\text { Mazhab: } \\
\text { Shafi'i ; } \\
\text { dalil hukum } \\
\text { yang } \\
\text { digunakan } \\
\text { dalam } \\
\text { menetapkan } \\
\text { hukum } \\
\text { Islam adalah } \\
\text { al-Qur'an, } \\
\text { al-Hadith, } \\
\text { ljma' dan } \\
\text { Qiyas. } \\
\text { Di samping } \\
\text { itu } \\
\text { pendekatan } \\
\text { al-maslahah } \\
\text { menjadi } \\
\text { salah satu } \\
\text { favorit } \\
\text { pendekatann } \\
\text { ya dalam } \\
\text { merumuska } \\
\text { n hukum } \\
\text { Islam yang } \\
\text { didialogkan } \\
\text { dengan } \\
\text { aspek } \\
\text { lokalitas dan } \\
\text { realitas } \\
\text { sosial } \\
\text { kekinian. }\end{array}$ & $\begin{array}{l}\text { Kekuatanny } \\
\text { a: } \\
\text { darūrät, häjät, } \\
\text { tabsinät } \\
\text { (masing- } \\
\text { masing } \\
\text { menyangkut } \\
\text { pemeliharaa } \\
\text { n terhadap } \\
\text { agama, jiwa, } \\
\text { akal, } \\
\text { keturunan } \\
\text { dan harta). } \\
\text { Cakupan: } \\
\text { Maslahah } \\
\text { dunyawiyah } \\
\text { dan } \\
\text { maslahah } \\
\text { ukhrawiyah } \\
\text { Legalitas: } \\
\text { Semua } \\
\text { maslahah } \\
\text { legal tapi } \\
\text { disesuaikan } \\
\text { dengan naș, } \\
\text { melalui } \\
\text { reaktualisasi } \\
\text { hukum } \\
\text { Islam } \\
\text { dengan } \\
\text { pendekatan } \\
\text { keilmuan } \\
\text { Islam dan }\end{array}$ & $\begin{array}{l}\text { Ijtihadi dan } \\
\text { sesuai } \\
\text { prosedur } \\
\text { ijtihad } \\
\text { dengan } \\
\text { sangat } \\
\text { memperhitun } \\
\text { gkan } \\
\text { kepentingan } \\
\text { publik } \\
\text { (mașlahat } \\
\text { al-'́mmab). }\end{array}$ & $\begin{array}{l}\text { Sebagai } \\
\text { pendekatan } \\
\text { dalam } \\
\text { penggalian } \\
\text { hukum } \\
\text { terutama } \\
\text { dalam } \\
\text { wilayah } \\
\text { muamalah. }\end{array}$ \\
\hline
\end{tabular}




\begin{tabular}{|l|l|l|l|}
\hline & $\begin{array}{l}\text { teori-teori } \\
\text { sosial Barat. }\end{array}$ & & \\
\hline
\end{tabular}

\section{Kesimpulan}

Sebagai seorang cendekiawan muslim progresif Gus Dur tidak mau terpaku pada pemikiran dan gagasan yang berbau fomalitas belaka. Progresifitas pemikirannya terlihat dalam tafsiran-tafsirannya atas problematika sosialkeagamaan yang terjadi di Indonesia. Realitas sosial kemanusiaan selalu terbuka untuk ditafsirkan sesuai dengan semangat dan konteks zamannya. Tidak terkecuali dalam hal ini untuk kasus-kasus dan persoalan aktual yang terjadi di negara kita. Dalam pandangan Gus Dur umat Islam Indonesia harus proaktif dan kreatif dalam memandang pemikiran, ide, dan gagasan yang telah dicanangkan oleh para ulama klasik. Ide dan gagasan mereka dimunculkan untuk menjawab persoalan-persoalan di zaman mereka dengan perangkat metodologi yang hingga kini diakui elenvitalnya. Menurut Gus Dur, dalam kerangka pengembangan metodologi inilah yang harus diupayakan semaksimal mungkin oleh umat Islam di era kekinian. Umat Islam tidak boleh puas hanya dengan berpegang pada penafsiran tekstual semata. Tetapi dimensi konteks dan realitas sosial zaman kekinian juga harus diperhatikan untuk mendapatkan pemahaman keislaman yang humanis, progresif dan komprehensif. ${ }^{31}$ Pada ranah inilah Gus Dur mengajak kita untuk berani berpikir sendiri (sapere aude) untuk menafsiri zaman kekinian kita dengan pemikirannya mengenai konsep mașlaḥah berbasis etika (maslaha based etbics).

\section{DAFTAR PUSTAKA}

Abdullah, M. Amin. 2002. Antara Al-Gharali dan Kant: Filsafat Etika Islam. Bandung: Mizan.

Abubakar, Al-Yasa', 2016, Metode Istislabiah Pemanfaatan Ilmu Pengetabuan dalam Ushul Fiqh. Jakarta: Prenada Media Group.

Ahmad, Munawar, 2010, Ijtibad Politik Gus Dur Analisis Wacana Kritis, Yogyakarta: LKiS.

\footnotetext{
${ }^{31}$ Dalam konteks ini bisa dipahami jika Gus Dur sangat akrab dengan wacana-wacana tentang keadilan (al-'adalah), kesejahteraan bersama (mașlaḥah al-'āmmah), ekonomi kerakyatan (al-iqtișad al-ra'iyyah), demokrasi (al-dimaqratiyyah), dan kebebasan (alhurriyyah). Pemikiran Gus Dur yang mengusung nilai-nilai tersebut senada dengan pemikiran yang diusung oleh M. Al-Thahir Ibn 'Ashur. Lihat selengkapnya dalam Ibn 'Āshūr, Muḥammad Tāhir, 2001, Maqāṣid al-Sharīah al-Islāmiyyah, Beirut: Dar alNafais.
} 
Ainurrofiq (Ed.), 2002, "Mą̧ab Jogja" Menggagas Paradigma Ushul Fiqh Kontemporer, Djogjakarta: Ar-Ruzz Media.

Arifi, Ahmad, 2010, Pergulatan Pemikiran Fiqih "Tradisi" Pola Mą̧̧ab, Yogyakarta: eLSAQ.

Arif, Syaiful, 2013, Humanisme Gus Dur Pergumulan Islam dan Kemanusiaan, Yogyakarta: Ar-Ruz Media.

Auda, Jasser, 2008, Membumikan Hukum Islam Melalui Maqasid Syariah Pendekatan Sistem, Terjemah oleh Rosidin dan 'Ali 'Abd el-Mun'im. 2015, Bandung: Mizan.

Aziz, Munawir, (Ed.), 2013, Epistemologi Fiqh Sosial Konsep Hukum Islam dan Pemberdayaan Masyarakat, Purworejo Margoyoso Pati Jawa Tengah: Fiqh Sosial Institute Kampus STAI Mathali’ul Falah.

Barton, Greg, 2002, Biografi Gus Dur The Authorized of Abdurrahman Wabid, Terjemahan oleh Lie Hua, 2003. Yogyakarta: LKiS.

Biyanto, 2015, Filsafat Ilmu dan Ilmu Keislaman, Yogyakarta: Pustaka Pelajar. al-Būțī, Muḥammad Sa’īd Ramaḍān, 1973, Dawabit al-Mașlaḥahfi al-Shariah al-Islämiyyah, Beirut: Muassasah al-Risalah.

Dahlan, Moh. 2013, Paradigma Ushul Fiqh Multikultural Gus Dur, IAIN Bengkulu Press-Kaukaba Dipantara.

, 2009. Abdullah Ahmed an-Na’im: Epistemologi Hukum Islam. Yogyakarta: Pustaka Pelajar.

Dzulmanni (ed.). 2005. Islam Liberal dan Fundamentalisme Sebuah Pertarungan Wacana. Yogyakarta: eLSAQ Press.

Ghofur, Abdul, 2002, Demokratisasi dan Prospek Hukum Islam di Indonesia, Yogyakarta: Pustaka Pelajar.

Ibn 'Āshūr, Muḥammad Tāhir, 2001, Maqāșid al-Shariah al-Islämiyyah, Beirut: Dar al-Nafais.

al-Qardhawi, Yusuf, 1424, Membumikan Syariat Islam Kelunesan Aturan Ilabi untuk Manusia, Terjemahan oleh Ade Nurdin dan Riswan, 2003, Bandung: Mizan.

Kholish, M. Anas, dan Salam, Nor, 2015, Epistemologi Hukum Islam Transformatif Sebuah Tawaran Metodologis dalam Pembacaan Kontemporer, Malang: UIN-Maliki Press. 
al-Shāịibī, Abū Ishāq Ibrahīm al-Lakhmī. Tanpa Tahun. Al-Muwāfaqat fì Ușū al-Ahkēm. Beirut: Där al-Fikr.

Mahfudz, M.A. Sahal. 2003. Figh Sosial: Upaya Pengembangan Madzhab Qauli dan Manhaji. Postra: Vol. II. No. 2.

1994. Nuansa Fikih Sosial Yogyakarta: LKiS.

Mawardi, Ahmad Imam. 2010. Fiqih Minoritas, Fiqh Al-Aqalliyyat dan Evolusi Maqashid al-Shariah dari Konsep ke Pendekatan. Yogyakarta: LKiS.

Nurul Janah, Tutik. 2015. (Ed.). Metodologi Fiqh Sosial Dari Qauli Menuju Manhaji. Jawa Tengah: Figh Sosial Institute STAI Mathali'ul Falah.

Parera, Frans M. dan Koekerits, T. Jakob (Eds.). 2010. Gus Dur Menjawab Perubahan Zaman Warisan Pemikiran K.H. Abdurrabman Wabid. Jakarta: PT Kompas Media Utama.

Roy Purwanto, Muhammad. 2014. Dekonstruksi Teori Hukum Islam Kritik terhadap Konsep Mashlahah Najmuddin al-Thufi. Yogyakarta: Kaukaba Dipantara.

Suseno, Franz Magnis 13 Tokoh Etika (Yogyakarta: Kanisius, 1997)

al-Turabi, Hasan. Tanpa Tahun. Fiqih Demokratis Dari Tradisionalisme Kolektif Menuju Modernisme Populis. Terjemahan oleh Abdul Haris dan Zaimul Am. 2003. Bandung: Arasy.

Wahid, Abdurrahman. 2011. Tuhan Tidak Perlu Dibela. Yogyakarta: LKiS.

2007. Islam Kosmopolitan Nilai-Nilai Indonesia dan Transformasi Kebudayaan. Jakarta: The Wahid Institute. 2006. Islam Ku Islam Anda Islam Kita Agama Masyarakat Negara Demokrasi.Jakarta: The Wahid Institute. 2002. Kumpulan Kolom dan Artikel Abdurrabman Wabid Selama Era Lengser. Yogyakarta: LKiS.

2001. Pergulatan Negara, Agama, dan Kebudayaan. Jakarta: Desantara. 1999. Prisma Pemikiran Gus Dur. Yogyakarta: LKiS.

Wahid, Abdurrahman. November, 1987. Fiqh dan Etika Sosial. Aula. No. 09 Tahun IX. 